\title{
THE OFFER OF TOURISM AND RECREATION BUSINESS ENTITIES UNDER SOCIAL PROGRAMMES ON THE EXAMPLE OF THE LARGE FAMILY CARD
}

\author{
IWONA JÓZEFOWICZ, ${ }^{1}$ HANNA MICHNIEWICZ-ANKIERSZTAJN ${ }^{2}$
}

Kazimierz Wielki University in Bydgoszcz, POLAND

Faculty of Physical Education, Health and Tourism, Institute of Geography

${ }^{1}$ e-mail: jozefowicz@ukw.edu.pl

2e-mail: hanka@ukw.edu.pl

JEL CODES

KEYWORDS

ABSTRACT
D31, L83, M14

social tourism, Large Family Card (LFC), Corporate Social Responsibility (CSR)

Contemporary tourism enterprises operating in market economy more and more often implement the policy of corporate social responsibility, which is conditioned by their business mission. An increasing number of economic entities decide to take part in prosocial programmes oriented at, among others, families in special situations. The article aims to demonstrate the involvement of economic entities taking part in the nationwide Large Family Card (LFC) programme in Poland in the area of tourism and leisure. The results of surveys have shown that despite the fact that economic entities participating in the programme are mostly based in areas where tourist traffic is very intense, they eagerly provide small discounts to multi-child families.

The study was funded under grant for research covered by the Statutes of the University.

\section{Introduction}

Contemporary tourism enterprises operating in market economy more and more often implement the policy of corporate social responsibility.One of its elements is looking after the interests of local communities and of the whole society (Labocha, 2017). The implementation of the assumptions of corporate social responsibility (CSR) is also a component of the concept of social tourism. By facing social issues, the company can generate new ideas to solve its business problems. 
In addition, if the company is able to satisfy the needs of the society, it could be easier for it to satisfy the needs of its customers (Janeš et al., 2017, p. 178). Every company has a business model (BM), whether articulated or not.At its heart, a BM performs two important functions:value creation and value capture. An increasing number of enterprises, including those in the tourist industry, have implemented business models matching the concept of sustainable development. In turn, some models are classified as aiming at social innovation. This paper is focused particularly on BMs implementing the rule of social responsibility through: using profits earned from the sale of a product/service to donate a similar product/service to those in need, building new markets in innovative and socially responsible ways, and using different pricing (charging more to those who can afford it in order to subsidize those who cannot) (Zilahy, 2016, p. 64).

This article aims to demonstrate the involvement of economic entities taking part in the Large Family Card (LFC) programme in Poland in the area of tourism and leisure.The subjective scope covers the analysis of territorial distribution of the above-mentioned entities with reference to selected demographic and economic indicators, and the analysis of the number and amount of discounts offered to multi-child families. Thus, following research hypotheses were postulated:

- the number of entities participating in the Large Family Card programme is directly proportional to the number of multi-child families,

- entities offering discounts for LFC holders are mainly based in voivodeships with a high intensity of tourist traffic, whereas the discounts they offer are higher than discounts offered in other voivodeships

All entities registered in the LFC programme were covered by statistical analysis in the following categories:cultural institution - museum, sport, leisure, tourism - holiday resorts, and sports and leisure centres.In addition, tourist function indicators were used (e.g. Charvat index of the intensity of tourist traffic). Surveys and inquiries were carried out in the first quarter of 2017.

\section{Corporate social responsibility policy and social tourism}

Corporate social responsibility (CSR) defined in the Green Paper published by the European Commission is defined as voluntary consideration of social and ecological aspects by the company in its commercial activities and relations with stakeholders (Green Paper, 2001). In the evaluation of the entities, compliance with CSR rules can be interpreted as philanthropy (voluntary activity, pro publico bono) or as a legal obligation stemming from, for instance,environmental protection regulations or as the result of the calculation of expenditure and deliverables (losses and profits) in their own interest. At the same time, CSR is a business strategy (Mazur-Wierzbicka, 2012). A company engaged with CSR's policies "should develop its social responsibilities in the following basic areas:principles, moral values and company ethics, management of the human resources at the company, relations with the company's local community, protection of the local and global environment, policies of marketing and company communication" (Pérez-Aranda, 2014, p. 45).

Surveys indicate that such a strategy can be profitable from the point of view of an economic entity. It refers to both international corporations and small and medium-sized enterprises. 
The Report entitled Green is Gold (Goldman Sachs) shows that the stock exchange performance of companies being corporate social responsibility leaders is on average higher by $25 \%$ (Sysko-Romańczuk, Roszkowska, Niedźwiecka, 2012, p. 35). 80\% of Americans claim that the ethical attitude, behaviour and practices of the company have direct influence on their willingness to purchase the company's products (Social Responsibility: Key to Building Reputation and Regaining Trust, 2004, p. 2). Despite the fact that in Poland the effect of corporate social responsibility is less significant than in the United States, it can be assumed that the involvement of tourism enterprises in prosocial programmes has a positive effect on their corporate image and it can improve the economic standing of such businesses.Social economics comprises a wide range of phenomena (Reichel, 2010). With reference to tourism, it means that not only enterprises operating in the tourist segment of the market are established but such forms of social enterprise are also regarded as a way of social inclusion of people who were previously excluded from tourist activities. Therefore, it can be deemed an element of social policy (Galor, Majewski, 2011). On the other hand, the interest of businesses in being involved in programmes such as Large Family Card can be a result of their will to increase the competitive edge of the company and at the same time to improve the social and economic conditions for citizens living in the local community in which the company operates. Such activities are inscribed in the Shared Value Concept which also emphasizes the significance of corporate social responsibility. These practices increase the competitive edge of the company, while at the same time improving economic and social conditions (Porter, Kramer, 2011, p. 6). They assume that economic value will be created by creating social value (what is good for the community is also good for business). It is significant because a contemporary consumer of services in the area of tourism and leisure more and more often becomes a prosumer, that is, a consumer involved in co-creation and promotion of their favourite brands of products (Kuźniar, Surmacz, 2015, p. 26). Profit earned based on the concept of shared value enables faster development of communities and increases the rate of growth of businesses (Sysko-Romańczuk, Roszkowska, Niedźwiecka, 2012, p. 32).

In order to demonstrate the advisability of prosocial measures taken by entities dealing with tourism, first the methods of expenditure from the family's (household's) budget must be analysed. The data provided by the Central Statistical Office of Poland for 2015 was used for the purposes of analysing the income and expenses of households on the voivodeship scale, with a particular focus on the costs related to involvement in tourism, leisure and culture.Out of the sixteen voivodeships, only in Masovian voivodeship the average available per capita income exceeded PLN 1,700 per household. Four other voivodeships: Lower Silesian, Silesian, Lubusz and West Pomeranian recorded income about $2 \%$ higher than the national average, whereas the lowest average income - less than PLN 1,081 - was noted down in Subcarpathian voivodeship. The level of income in respective voivodeships was generally reflected in the amount and structure of monthly household expenditure. The highest expenditure on culture and leisure per household was recorded in Masovian voivodeship (8.4\% of total expenditures), Łódź voivodeship (7.5\%), or Lower Silesian voivodeship (7\%). However, it is notable that more than $7 \%$ of the amount (per capita) spent on culture and leisure derived from household budget in voivodeships where the available income per capita in 
a household was lower than the national average, i.e. in Łódź and Opole voivodeships. The lowest expenditure on leisure and culture per capita was observed in households in Subcarpathian and West Pomeranian voivodeships (5.3\%) and in Świętokrzyskie voivodeship (5.4\%). It is analogous in the case of expenditure on hotels and restaurants. Here, the leaders are also households from Lower Silesian voivodeship (5.5\%), Masovian voivodeship (5.3\%) as well as Opole and Łódź voivodeships (4.5 and 4.1\% respectively). Households in Subcarpathian voivodeship allocated the lowest amounts for this purpose $-2.9 \%$. Thus, the financial standing of households reflects their ability to take part in tourism and leisure activities. For this reason, measures oriented at families in a special situation have become significant with a view to increasing the tourist consumption. These include but are not limited to prosocial programmes, for example the Large Family Card or the Senior Card.

Social tourism is defined as a set of relations and procedures resulting from the implementation of state-funded programmes in order to provide citizens having lower income with a possibility to take part in tourism activities (Analysis of the development of social tourism in Poland. Status, chances and risks, p. 3). According to the authors, the system of discounts offered under such programmes matches the idea of social tourism because it provides an opportunity to use, among other benefits, reduced prices offered by cultural institutions, leisure centres or museumsthroughout Poland. Thus, the Card provides large families with easy access to leisure activities and reduces daily cost of living ${ }^{1}$ (https://rodzina.gov.pl/duza-rodzina/karta-duzej-rodziny, 17.05.2017). The earliest definition of social tourism by Hunzicker (1951) describes social tourism as "the relationships and phenomena in the field of tourism resulting from participation in travel by economically weak or otherwise disadvantaged elements in society". Subsequent publications also define social tourism as tourism with additional moral value mainly aiming at using tourist exchange services (Minnaert et al., 2007; Minnaert et al., 2009; Minnaert et al., 2011). Apart from state institutions, the stakeholders of social tourism on the supply side include commercial entities supporting socially useful projects. Among the beneficiaries of this segment of tourism there are families in a special situation, including but not limited to families exposed to social exclusion, including multi-child families.

\section{Large Family Card (LFC) as an element of corporate social responsibility policy}

Social tourism includes, among others, activities to facilitate the use of services related to broadly understood tourism and leisure. The Large Family Card (LFC) is a system of discounts and additional benefits for families with three and more children both in public institutions and in private businesses. In turn, the involvement of public institutions and private sector entities in creating the programme contributes to improving their recognisability and it can generate measurable financial benefits by increasing the number of people using their offer, e.g. in the area of culture, leisure or sports.

${ }^{1}$ https://rodzina.gov.pl/duza-rodzina/karta-duzej-rodziny (17.05.2017). 
The first of the research assumptions made by the authors with regard to relationships between the supply side and the beneficiaries of the LFC programme was verified based on the results of analyses concerning territorial distribution of the multi-child families according to the nomenclature of territorial units for statistics NTS 2 (based on National Census Data from 2011). Another verification criterion was the number and structure of the entities involved in the LFC programme.

As regards the number and distribution of entities involved in the LFC programme in Poland, they were clearly concentrated within the area of two voivodeships: Lesser Poland and Masovian voivodeship. In both it was reflected in the ratio of concentration of multi-child families (Figure 1). On the other hand, an inversely proportional relationship was observed in Greater Poland voivodeship.

a)

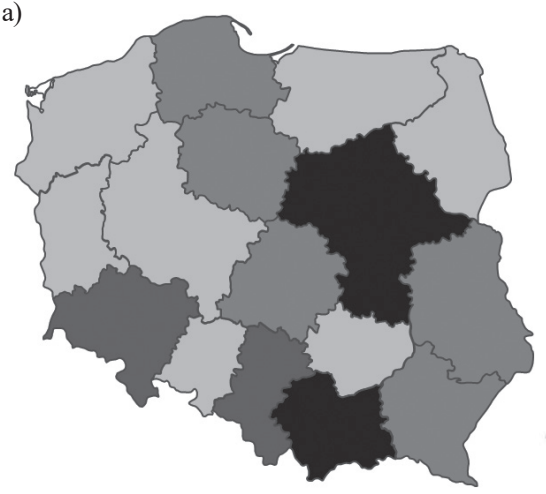

b)

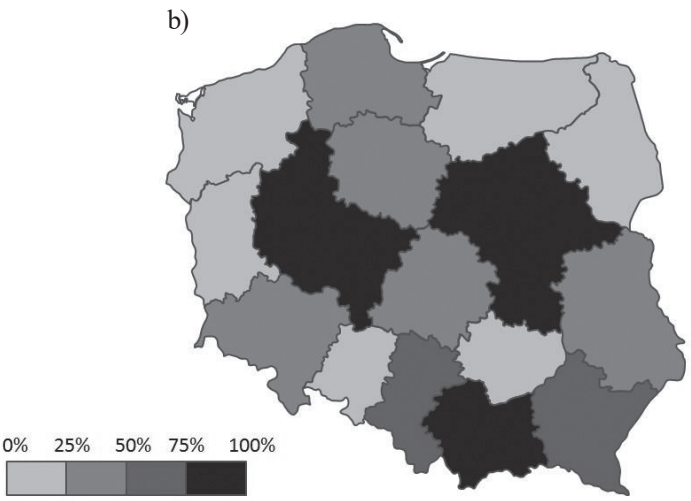

Figure 1. Territorial distribution of (a) selected economic entities involved in the LFC programme and (b) multi-child families in Poland in 2017

Source: author's compilation based on LFC data, https://rodzina.gov.pl/duza-rodzina/karta-duzej-rodziny (17.05.2017) and 2012 Census, www.stat.gov.pl (30.04.2017).

The structure of entities offering the analysed services related to tourism, leisure and culture (sports centres, holiday resorts and museums) in respective voivodeships differed in terms of their percentage share. The largest disparities were observed in West Pomeranian, Podlaskie and Greater Poland voivodeships. Museums in West Pomeranian and Greater Poland voivodeship and holiday resorts in Podlaskie voivodeship were not involved in the LFC programme. However, the percentage share of the above-mentioned services was even in Masovian, Lublin and Lesser Poland voivodeships (Figure 2). 


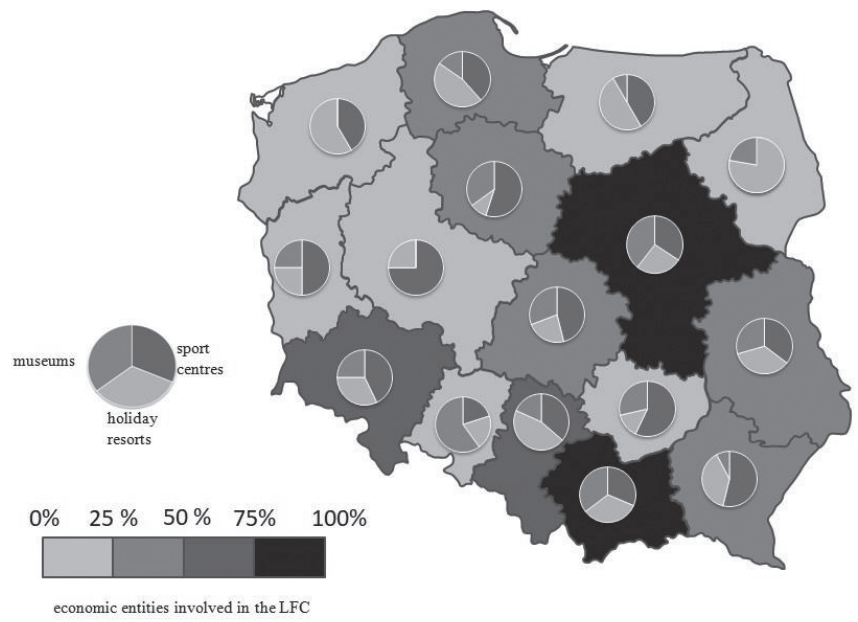

Figure 2. Structure of entities involved in the LFC programme offering selected services in the area of tourism and leisure in 2017

Source: authors compilation based on LFC, https://rodzina.gov.pl/duza-rodzina/karta-duzej-rodziny (17.05.2017).

Analysing the involvement of holiday resorts in the programme using the tourist traffic intensity by Charvat rate (the quotient of the number of nights spent per year to the number of inhabitants) calculated for voivodeships in 2015 (Figure 3), it is noticeable that they were most numerous in the areas with the highest intensity of tourist traffic (West Pomeranian, Pomeranian and Lesser Poland voivodeship:respectively 30.1, 21.7 and 10.3\% of all holiday resorts). In turn, in Lesser Poland and Masovian voivodeships the predominant entities offering discounts were museums (respectively 14.5 and $14.7 \%$ ).

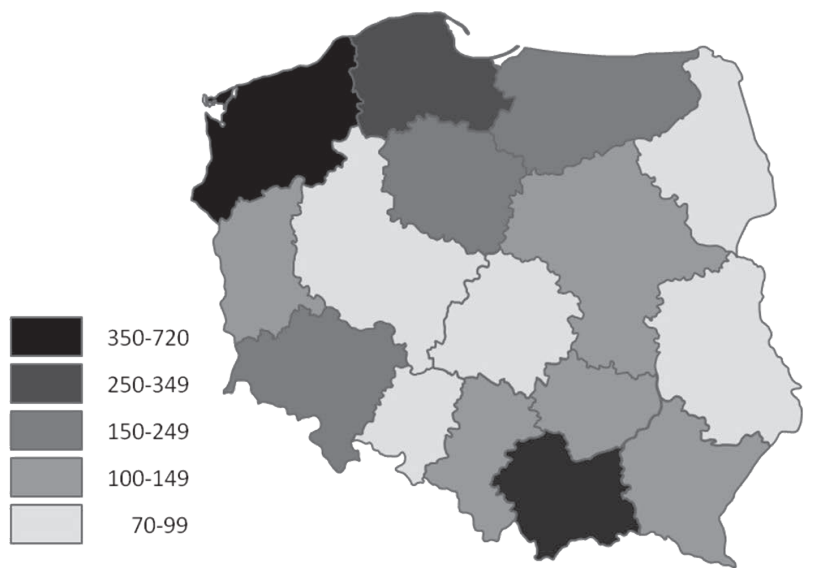

Figure 3. Tourist traffic intensity by Charvat by voivodship in 2015

Source: own elaboration based on Turystyka w 2015. Retrieved from: www.stat.gov.pl (29.04.2017), p. 91. 
Economic entities involved in the LFC programme most often grant $10-15 \%$ discounts $(27.6 \%$ of all the surveyed entities). A slightly lower number of such entities grant discounts ranging from 16 to $20 \%$ (ca. $22 \%$ of all entities). Only $5 \%$ of entities offer discounts above $50 \%$ (whereas nearly $3 \%$ of entities in that group offer their services free of charge) (Table 1).

Table 1. Structure of discounts offered by enterprises involved in the LFC programme According to type of activity

\begin{tabular}{|c|c|c|c|c|c|c|c|c|c|c|c|}
\hline \multirow[b]{2}{*}{ Type of enterprise } & \multicolumn{11}{|c|}{ Level of discounts } \\
\hline & $\begin{array}{c}\text { under } \\
10 \%\end{array}$ & $10-15 \%$ & $16-20 \%$ & $21-30 \%$ & $31-40 \%$ & $41-50 \%$ & $51-60 \%$ & $61-70 \%$ & $71-80 \%$ & $81-90 \%$ & $\begin{array}{c}91- \\
100 \%\end{array}$ \\
\hline Sport centres & 33 & 32 & 14 & 3 & 11 & 0 & 0 & 0 & 0 & 1 & 0 \\
\hline Holiday resorts & 14 & 48 & 24 & 7 & 3 & 4 & 0 & 0 & 0 & 0 & 0 \\
\hline Museums & 1 & 3 & 1 & 6 & 7 & 28 & 0 & 0 & 1 & 1 & 7 \\
\hline Total & 48 & 83 & 39 & 16 & 21 & 32 & 0 & 0 & 1 & 1 & 7 \\
\hline
\end{tabular}

Source: own elaboration based on https://rodzina.gov.pl/duza-rodzina/wyszukiwanie-partnerow-karty-duzej-rodziny (17.02.2017).

Despite the fact that entities involved in the LFC programme are concentrated in voivodships with high intensity of tourist traffic, the assumption regarding the amount of discounts offered is not confirmed (Figure 3). A detailed analysis of the structure of discounts in respective voivodeships showed that in West Pomeranian and Pomeranian voivodeships no entity offered discounts on their services exceeding 50\%. In Lesser Poland voivodeship it is only $1 \%$ of all entities from that area.

\section{Conclusions}

Factors determining tourism and leisure activity of a family include both the level of income and the size of household. There is a "clear negative correlation between the size of a household and its annual expenditure on tourism" (Kowalczyk-Anioł, Włodarczyk, 2011, p. 13). Higher income (per capita) increases the capacity to buy consumer goods and services, including tourist goods and services (Szromek, 2013, p. 342). According to the authors, the function of LFC matches the idea of social tourism because it provides an opportunity to use reduced prices offered by cultural institutions, leisure centres or museums throughout Poland. Thus, the Card provides large families with easy access to leisure activities and reduces daily cost of living. ${ }^{2}$

The following conclusions can be drawn based on the presented analysis of data:

- in voivodeships with the highest percentage of multi-child families, expenditure on leisure and tourism are high in Masovian voivodeship, and they are below the average for Poland in Greater Poland and Lesser Poland voivodeship,

- the number of entities involved in the Large Family Card programme is directly proportional to the number of multi-child families.It is clearly visible in Masovian and Silesian voivodeships. In the third voivodeship - Greater Poland, which is one of the voivodeships

${ }^{2}$ https://rodzina.gov.pl/duza-rodzina/karta-duzej-rodziny (17.05.2017). 
with the highest percentage of multi-child families, the number of entities dealing with tourism and leisure involved in the LFC programme is relatively low (Figure 1).

The second study assumption that entities offering discounts for LFC holders are mainly based in voivodeships with a high intensity of tourist traffic, whereas the discounts they offer are higher than discounts offered in other voivodeships, can be confirmed only in part. The analysis of territorial distribution indicates that most entities involved in the programme are located in voivodeships with the highest intensity of tourist traffic, but the discounts they offer are low - their level is similar in other voivodeships. At the same time, it should be emphasized that the rate of discounts depends on the type of activity and the form of ownership. Museums, which are mostly state-administered institutions, offered definitely higher discounts (37 institutions offered discounts higher than $50 \%$ of the ticket price, 7 of which had free of charge tickets). Holiday resorts and sports and leisure centres offered discounts at a definitely lower level.

Corporate social responsibility "focuses (...) on building full balance between the economic, ecological and social dimension of an enterprise" (Wołoszyn, Ratajczak, 2012, p. 14). In the light of reference literature, these dimensions also characterize the activities of enterprises in the area of sustainable development. However, Font et al. (2016) indicate that in many cases, responsible (sustainable) business is a result not so much of believing in the validity of the idea of sustainable development but rather of being convinced that the enterprises which undertake sustainability actions can provide a competitive, financial advantage. Moreover, societal legitimization is also mentioned - enterprises take sustainability actions which are visible or expected by others.

In the light of survey results, in the authors' opinion, economic entities involved in the LFC programme, fulfilling their mission connected with protecting cultural heritage and making it available, implement the corporate social responsibility policy to a larger extent. In other cases it seems that activities for the sake of programme beneficiaries aim at improving corporate identity and are linked to a specific marketing strategy.

Translated by mgr Magdalena Dolny

\section{Acknowledgment}

The study was supported by grant No BS-2016/K8/N1 financed at Kazimierz Wielki University in Bydgoszcz.

\section{Referencess}

Font, X., Garay, L., Jones, S. (2016). Sustainability motivations and practices in small tourism enterprises in European protected areas. Journal of Cleaner Production, 137, 1439-1448.

Galor, Z., Majewski, J. (2011). Po co turystyce polityka społeczna? Why does tourism need social policy? Folia Pomerania. Universitatis Technologiae Stetinensis, Oeconomica, 288 (64), 33-44.

Green Paper (2001). Promoting a European Framework for Corporate Social Responsibility, COM (2001) 366, Brussels 2001.

Hunziker, W. (1951). Social tourism: Its nature and problems. International Tourists Alliance Scientific Commission. 
Janeš, A, Biloslavo, R., Faganel, A. (2017). Sustainable Business Model: a Case Study of Fonda.si. Annals for Istrian and Mediterranean Studies Series Historia et Sociologia, 1 (27), 175-190.

Kowalczyk-Anioł, J., Włodarczyk, B. (2011). Turystyka rodzinna-istota i zakres pojęcia. In: J. Śledzińska, B. Włodarczyk (eds.), Turystyka rodzinna a zachowania prospołeczne (pp. 9-25). Warszawa: Wydawnictwo PTTK „Kraj”.

Kuźniar, W., Surmacz, T. (2015). Zastosowanie koncepcji współtworzenia wartości produktu w turystyce wiejskiejwybrane aspekty. Ekonomiczne Problemy Turystyki, 2 (30), Zeszyty Naukowe Uniwersytetu Szczecińskiego, 853. DOI: 10.18276/ept.2015.2.30-02.

Labocha, E., Społeczna odpowiedzialność biznesu-moda, czy konieczność. Retrieved from: www.sob.edu.pl/wp-content/ downloads/sob_moda_czy_koniecznosc.pdf.

Mazur-Wierzbicka, E. (2012). CSR w dydaktyce, czyli jak uczyć studentów społecznej odpowiedzialności. Szczecin: Stowarzyszenie Kreatywni dla Szczecina.

Minnaert, L., Maitland, R. Miller, G. (2009). Tourism and social policy - The value of social tourism. Annals of Tourism Research, 2 (36), 316-334.

Minnaert, L., Maitland, R., Miller, G. (2007). Social tourism and its ethical foundations. Tourism Culture \& Communication, 7, 7-17.

Minnaert, L., Maitland, R., Miller, G. (2011). What is social tourism? Current Issues in Tourism, 5, $403-415$.

Pérez-Aranda, J.A. (2014). The social responsibility as a model of tourist. Business and facilitating instruments for its implantation at the Spanish hotel sector. Ramon Llull Journal of Applied Ethics, 5 , 41-64.

Porter, M.E., Kramer, M.R. (2011). The Big Idea: Creating Shared Value. Harvard Business Review, 89 (JanuaryFebruary), 62-77.

Reichel, J. (2010). Znaczenie i rozwój ekonomii społecznej w Polsce. In: A. Stasiak (ed.), Turystyka społeczna w regionie tódzkim (pp. 11-22). Łódź: Wydawnictwo WSTH.

Social Responsibility: Key to Building Reputation and Regaining Trust (2004). The Wirthlin Report, 2 (13).

Sysko-Romańczuk, S., Roszkowska, P., Niedźwiecka, A. (2012). Odpowiedzialność biznesu. Teoria i praktyka. Management and Business Administration. Central Europe 2 (115), 26-40.

Szromek, A.R. (2013). Wskaźniki funkcji turystycznej i ich współzależność z innymi wskaźnikami ekonomicznymi na przykładzie polskiej gospodarki w latach 2000-2010. Prace Naukowe Uniwersytetu Ekonomicznego we Wrocławiu, Research Papers of Wrocław University of Economics, 304, Gospodarka turystyczna wregionie. Rynek turystyczny - współczesne trendy, problemy i perspektywy jego rozwoju, 336-349.

Wołoszyn, J., Ratajczak, M. (2012). Modele społecznej odpowiedzialności biznesu - rozważania teoretyczne. In: J. Wołoszyn (ed.), Społeczna odpowiedzialność biznesu w obszarze przedsiębiorczości (pp. 7-16). Warszawa: Wydawnictwo SGGW.

www.rodzina.gov.pl.

www.stat.gov.pl.

Zilahy, G. (2016). Sustainable Business Models - What Do Management Theories Say? Vezetéstudomány/Budapest Management Review, 10 (47), 62-72. 


\section{OFERTA PODMIOTÓW GOSPODARCZYCH Z ZAKRESU TURYSTYKI}

\section{REKREACJI W PROGRAMACH PROSPOŁECZNYCH W POLSCE} NA PRZYKŁADZIE KARTY DUŻEJ RODZINY

SŁOWA KLUCZOWE

STRESZCZENIE turystyka społeczna, Karta Dużej Rodziny (KDR), Polityka Społecznej Odpowiedzialności (CSR)

Współczesne przedsiębiorstwa turystyczne działające w realiach gospodarki rynkowej coraz częściej wdrażają politykę społecznej odpowiedzialności biznesu przy czym jest to uwarunkowane misją przedsiębiorstwa. Coraz więcej podmiotów gospodarczych decyduje się na udział w programach prospołecznych m.in. skierowanych do rodzin w specjalnej sytuacji. Celem artykułu jest ukazanie udziału podmiotów gospodarczych uczestniczących w ogólnopolskim programie Karta Dużej Rodziny (KDR) w Polsce w zakresie turystyki i rekreacji. Wyniki przeprowadzonych badań wykazały, że pomimo koncentracji podmiotów gospodarczych uczestniczących w programie na obszarach o dużym natężeniu ruchu turystycznego chętnie udzielają niewielkich zniżek dla rodzin wielodzietnych. 